\title{
The effect of dietary protein content and feeding level on the rate of protein deposition and energy utilization in growing Iberian pigs from 15 to $50 \mathrm{~kg}$ body weight
}

\author{
R. Nieto, A. Miranda, M. A. García and J. F. Aguilera* \\ Unidad de Nutrición Animal, Estación Experimental del Zaidín (CSIC), Camino del Jueves s/n, 18100 Armilla, Granada, \\ Spain
}

(Received 2 July 2001 - Revised 21 January 2002 - Accepted 15 February 2002)

\begin{abstract}
The effects of dietary protein content and feeding level on the utilization of metabolizable energy (ME) and on the rates of gain, protein and fat deposition have been studied in seventy-two Iberian pigs growing from 15 to $50 \mathrm{~kg}$ body weight (BW) by means of comparative slaughter experiments. The animals were fed on six diets providing 223, 192, 175, 156, 129 and $101 \mathrm{~g}$ crude ideal protein $(\mathrm{N} \times 6 \cdot 25 ; \mathrm{CP}) / \mathrm{kg} \mathrm{DM}$ and $14.64,14 \cdot 14,14.37,14 \cdot 80,15.36$ and $15.53 \mathrm{MJ} \mathrm{ME} / \mathrm{kg}$ DM respectively. Each diet was offered at three levels of feeding: $0 \cdot 60,0.80$ and $0.95 \times$ ad libitum intake. Protein deposition (PD) increased significantly $(P<0.01)$ with each decrease in dietary $\mathrm{CP}$ content and reached a maximum value $(74.0 \mathrm{~g})$ when the diet providing $129 \mathrm{~g} \mathrm{CP} / \mathrm{kg} \mathrm{DM}(6 \cdot 86 \mathrm{~g}$ digestible ideal protein/MJ ME) was offered at the highest feeding level. This feeding regimen resulted in average values for live-weight gain and retained energy (RE) of $559 \mathrm{~g} / \mathrm{d}$ and $10.9 \mathrm{MJ} / \mathrm{d}$ respectively. RE increased significantly $(P<0.001)$ from 480 to $626 \mathrm{~kJ}^{\prime} / \mathrm{kg} \mathrm{BW}^{0.75}$ with each decrease in dietary CP content from 192 to $129 \mathrm{~g} /$ $\mathrm{kg}$ DM. Raising the level of feed intake led to significant linear increases in PD and RE irrespective of the diet fed $(P<0 \cdot 001)$. When diets approaching an adequate supply of $\mathrm{CP}$ were given, the net efficiency of use of ME for growth $\left(\mathrm{k}_{\mathrm{w}}\right)$ and the maintenance energy requirements were $58.2 \%$ and $422 \mathrm{~kJ} / \mathrm{kg} \mathrm{BW}^{0.75}$ per d respectively.
\end{abstract}

Protein deposition: Energy retention: Requirements: Iberian pigs

The productive performance of the growing pig is known to be determined basically by the protein concentration of the diet and the level of energy intake. Knowledge of this relationship is critical to predict the pig's response to changes in energy or amino acids supply. Short-term experiments involving balance studies or long-term treatment trials using the comparative slaughter approach have been carried out to provide information on this subject. An analysis of the evidence available indicates that in the growing pig protein deposition (PD) can be described as a protein-dependent process below an optimal protein supply per unit of energy. A linear relationship has been reported up to a breakpoint beyond which protein accretion depends largely on energy supply (Campbell et al. 1984, 1985; Kyriazakis \& Emmans, 1992). Two variables have been proposed (Fuller et al. 1995) to describe the response of the growing pig to changes in energy and protein supply: (1) the maximum daily rates of protein accretion; (2) the marginal efficiency of body protein accretion, measured as the change in daily PD per unit change in daily metabolizable energy (ME) at restricted intakes $(\Delta \mathrm{PD} / \Delta \mathrm{ME} ; \mathrm{g} / \mathrm{MJ})$. Both variables are determined by genotype and endocrine status, so that the optimal protein:energy ratio may well vary between breeds with different genetic potential for protein accretion. There is a lack of information on this relationship in the Iberian pig, a breed with a low potential for PD. In the absence of specific experimental support, feed formulation for the growing Iberian pig has been based on the recommendations reported for modern high-performing pigs, for which their requirements are presently well defined in terms of ideal protein and ME (National Research Council, 1998). Within this context, the purpose of the present work was to determine the effects of dietary protein content and level of feeding on growth performance, PD and energy utilization of Iberian pigs from 15 to $50 \mathrm{~kg}$ live weight.

\footnotetext{
Abbreviations: BW, body weight; CP, crude protein; DE, digestible energy; GE, gross energy; ME, metabolizable energy; PD, protein deposition; RE, retained energy.

*Corresponding author: Dr J. F. Aguilera, fax +34 958 572753, email aguilera@eez.csic.es
} 
For this purpose, a wide range of protein:energy values to ensure maximum PD were assayed. A brief account of some preliminary results have been given elsewhere (Nieto et al. 2001b).

\section{Materials and methods}

\section{Design}

The experiment included eighty-one castrated male Iberian pigs, twenty-seven from each of three blocks. Nine pigs (three from each block) formed an initial slaughter group. The rest were randomly assigned at $15 \mathrm{~kg}$ body weight (BW) to one of eighteen experimental dietary treatments following a 6 (dietary protein content) $\times 3$ (feeding level) factorial design with four replicates per combination of treatments. As only twenty-four individual pens were available the treatments were replicated in three blocks with one or two pigs per combination of treatments. Six diets with similar ME concentration and crude protein (CP) content varying from 223 to $101 \mathrm{~g} / \mathrm{kg} \mathrm{DM}$ were assayed each given at three daily rates: $0.95,0.80$ and $0.60 \times$ ad libitum intake.

\section{Animals}

Three groups of pure bred male Iberian pigs of Silvela strain from a single breeding company were used. They were castrated at $12 \mathrm{~kg} \mathrm{BW}$ and given a standard diet ad libitum until they reached $15 \mathrm{~kg}$ when those selected for initial slaughter were killed. All the others were moved to $2 \mathrm{~m}^{2}$ individual pens, located in a controlled environment room $\left(19 \pm 1 \cdot 5^{\circ} \mathrm{C}\right)$ and randomly assigned to an experimental treatment until they reached $50 \mathrm{~kg}$ when they were slaughtered. Water was freely available. During the experiment, the pigs were weighed once per week before feeding and the daily food allowance for each pig for the following week was adjusted accordingly.

\section{Diets and feeding}

Six isoenergetic diets differing in protein content, but of constant amino acid composition, were prepared by diluting a diet with a high-protein content (Table 1) with a protein-free mixture made of starch, cellulose, vegetable oil and a mineral-vitamin premix (diets A-F, Table 2). The high-protein diet was based on barley, soyabean and fish meal and formulated according to the ideal protein concept (Agricultural Research Council, 1981). Each diet was given at the three rates of feeding mentioned earlier, in two equal daily meals. An estimation of the ad libitum intake, defined as what the pig would consume when given sole access to its diet for two periods of $60 \mathrm{~min} / \mathrm{d}$, had been previously obtained with diets of the same nature as those used in the present experiment offered to castrated male Iberian pigs $(20-50 \mathrm{~kg} \mathrm{BW})$, which were placed in pens with individual feeding spaces (Nieto et al. 2001a). The daily allowance was calculated based on the pig's BW,
Table 1. The composition and chemical analysis of the high-protein (HP) diet and of a diluting mixture based on maize starch

\begin{tabular}{|c|c|}
\hline \multicolumn{2}{|l|}{ HP diet $(\mathrm{g} / \mathrm{kg})$} \\
\hline Barley grain & 733 \\
\hline Soyabean meal & 170 \\
\hline Fish meal & 65 \\
\hline Dicalcium phosphate & 8 \\
\hline Calcium carbonate & 12 \\
\hline Common salt & 5 \\
\hline Vitamin-mineral premix ${ }^{*}$ & 3 \\
\hline L-Lysine & 3 \\
\hline DL-Threonine & 1 \\
\hline \multicolumn{2}{|l|}{ Chemical composition (g/kg DM) } \\
\hline Crude protein $(\mathrm{N} \times 6.25)$ & 223 \\
\hline Lysine & $16 \cdot 16$ \\
\hline Methionine and cystine & $8 \cdot 21$ \\
\hline Threonine & 9.50 \\
\hline Tryptophane & 2.59 \\
\hline Isoleucine & 9.95 \\
\hline Leucine & $16 \cdot 08$ \\
\hline Histidine & 5.08 \\
\hline Phenylalanine and tyrosine & $18 \cdot 23$ \\
\hline Valine & 11.68 \\
\hline Gross energy (MJ/kg DM) & $18 \cdot 4$ \\
\hline Calculated digestible energy (MJ/kg DM) & $15 \cdot 2$ \\
\hline $\mathrm{DM}(\mathrm{g} / \mathrm{kg})$ & 885 \\
\hline \multicolumn{2}{|l|}{ Diluting mixture $(\mathrm{g} / \mathrm{kg})$} \\
\hline Cellulose & $45 \cdot 4$ \\
\hline Maize oil $†$ & $23 \cdot 0$ \\
\hline Dicalcium phosphate & $34 \cdot 0$ \\
\hline Common salt & $5 \cdot 0$ \\
\hline Vitamin-mineral premix ${ }^{*}$ & $3 \cdot 0$ \\
\hline Maize starch & $889 \cdot 6$ \\
\hline
\end{tabular}

measured once per week, according to the function:

$$
\begin{aligned}
\operatorname{voluntary} \text { intake }(\mathrm{g} / \mathrm{d})= & 448(\mathrm{SE} 48)+55 \cdot 0(\operatorname{sE} 1 \cdot 35) \\
& \times \mathrm{BW}(\mathrm{kg}) \\
& P<0 \cdot 001, \text { SE } 192, R^{2} 89 \cdot 1 .
\end{aligned}
$$

\section{Measurements}

The comparative slaughter procedure was used. Classical digestibility and balance trials were conducted at two or three different stages along the experiment: 68-82, 93107 and $>120 \mathrm{~d}$ of age. During the digestibility and balance experiments, animals were individually allocated in metabolic cages placed in a controlled environment room $\left(19 \pm 1 \cdot 5^{\circ} \mathrm{C}\right)$ to allow collection of faeces and urine separately. Animals were moved to the cages $5 \mathrm{~d}$ prior to starting excreta collection. Total collection of faeces and urine was performed daily for $5 \mathrm{~d}$. Urine was collected into $50 \mathrm{ml}$ $4 \mathrm{M}_{-} \mathrm{H}_{2} \mathrm{SO}_{4}$. At the end of the digestibility and balance experiment, a composite sample of faeces and urine was obtained for the whole period. The animals were slaughtered at $15 \mathrm{~kg}$ or $50 \mathrm{~kg} \mathrm{BW}$. After slaughter, the carcass and non-carcass parts were weighed separately. The animals 
Table 2. Nutrient composition of the experimental diets obtained by dilution of a high-protein (HP) diet with a mixture based on maize starch

\begin{tabular}{lcccccc}
\hline & \multicolumn{7}{c}{ Experimental diets } \\
\cline { 2 - 7 } & $\mathrm{A}$ & $\mathrm{B}$ & $\mathrm{C}$ & $\mathrm{D}$ & $\mathrm{E}$ & $\mathrm{F}$ \\
\hline HP diet $(\mathrm{g})^{*}$ & 1000 & 900 & 800 & 700 & 600 & 500 \\
Diluting mixture $(\mathrm{g})^{*}$ & 0 & 100 & 200 & 300 & 400 & 500 \\
Composition & & & & & & \\
CP $(\mathrm{N} \times 6 \cdot 25, \mathrm{~g} / \mathrm{kg} \mathrm{DM})$ & 223 & 192 & 175 & 156 & 129 & 101 \\
DE (MJ/kg DM) & 15.24 & 14.69 & 14.83 & 15.19 & 15.62 & 15.70 \\
ME (MJ/kg DM) & 14.64 & 14.14 & 14.37 & 14.80 & 15.36 & 15.53 \\
\hline
\end{tabular}

$\mathrm{CP}$, crude protein; $\mathrm{DE}$, digestible energy; $\mathrm{ME}$, metabolizable energy.

* For details of composition of HP diet and diluting mixture, see Table 1.

were divided into four components (carcass, head and feet, viscera and blood). Viscera and blood were weighed and kept at $-20^{\circ} \mathrm{C}$ for subsequent analysis; the carcasses with head and feet were chilled overnight, weighed and finally kept at $-20^{\circ} \mathrm{C}$ until analysis. The left half of the carcass and the rest of body components were minced separately, homogenized and samples were taken for freeze-drying and subsequent analysis. Samples were analysed separately for $\mathrm{CP}$ (total $\mathrm{N} \times 6.25$ ), gross energy $(\mathrm{GE})$ and ash. Body fat was calculated assuming an energy content of 23.8 and $39.3 \mathrm{~kJ} / \mathrm{g}$ for protein and fat respectively. Data from the initial slaughter group were used to estimate the body composition of the other seventy-two animals at the start of the trial. For that purpose the relationship between live weight and the empty BW at slaughter was calculated and applied with the analytical data of the initial group. Increases in protein, energy, fat and minerals were then calculated by difference between the estimated initial values and the observed final values.

Apparent digestible energy (DE) and ME contents were determined from the GE content of the feed consumed minus faecal energy or faecal plus urinary energy, respectively. Apparent energy digestibility and metabolizability were calculated as DE:GE and ME:GE ratios. Total N retention was determined from body composition as described earlier.

\section{Chemical analyses}

All analyses were performed in duplicate. The DM content of feeds and faeces was determined by standard procedures (Association of Official Analytical Chemists, 1975) and total $\mathrm{N}$ in feed, urine and in freeze-dried samples of body components (except for the blood) and of faeces by a Kjeldahl procedure using mineralization (Block Digestor Selecta S-509; J.P. Selecta, Abrera, Barcelona, Spain), distillation units (Büchi Laboratoriums Technik AG, Flawil, Switzerland) and titration units (Metrom AG, Herisau, Switzerland). Total ash determinations were carried out on feed and body component samples previously freezedried by standard procedures (Association of Official Analytical Chemists, 1975). Whenever an analysis was made on a freeze-dried material a DM determination was performed on another portion, in a ventilated oven, by standard procedures (Association of Official Analytical Chemists, 1975), to determine residual water content after freeze-drying and the corresponding analytical result expressed in a DM basis. GE was measured in an adiabatic bomb calorimeter (Gallenkamp Autobomb CBA 305; Loughborough, Leics., UK). GE determinations were performed on freeze-dried samples of feeds, body components, faeces and urine. The latter were freeze-dried in a polyethylene sheet of known energy value and their GE values were obtained by difference.

\section{Statistical treatment}

The experimental data were subjected to ANOVA as a randomized design with dietary protein content, level of feeding and experiment replicate (block) as factors, by means of a computer software package (1985; Statistical Analysis Systems Institute, Cary, NC, USA). As the block factor had no significant interactions with feeding level or protein content these were added to the error term in the model and the main effects were then checked.

Block effect was not significant and the design was rearranged as a two balanced factors analysis with feeding level and dietary protein content as main factors and four pigs in each cell. In this design dietary protein content $X$ feeding level interaction was first checked, and when not significant, main effects were studied by pairwise comparisons using the Tukey's method. A similar procedure was followed when analysing digestibility data from measurements at $68-82,93-107$ and $>120 \mathrm{~d}$ of age. Feeding level, dietary protein content and age were the main factors. As no significant interactions were found, main effects were studied by pairwise comparisons using the Bonferroni's test.

\section{Results}

During the experiments all pigs showed normal behaviour with no signs of illness, except some minor scouring problems which were easily overcome. However, one pig on the lowest feeding level stopped eating and was removed from the experiment. Some pigs on the highest level of feeding were unable to eat their full ration and the residues were quantitatively taken from the trough, dried and weighed to calculate their actual intakes.

The average daily DE and ME intakes were 15.5 and $15.1,20.7$ and 20.1 , and 24.2 and $23.7 \mathrm{MJ}$ respectively, according to the level of feeding assigned (Table 3). 
Table 3. The effects of protein content of the diet and level of feeding on the performance of growing lberian pigs between 15 and $50 \mathrm{~kg}$ live weight $†$

(Mean values for twelve pigs per dietary protein content group)

\begin{tabular}{|c|c|c|c|c|c|c|}
\hline & Food intake (kg DM/d) & DE intake (MJ/d) & ME intake (MJ/d) & Daily gain (g) & Food intake:gain & Gain:ME intake (g/MJ) \\
\hline \multicolumn{7}{|c|}{ DPC (g/kg DM) } \\
\hline 223 & $1 \cdot 351$ & $20 \cdot 57$ & $19 \cdot 76$ & $394^{a b c}$ & $3.43^{\mathrm{ab}}$ & $19 \cdot 9^{a b c}$ \\
\hline 192 & 1.325 & $19 \cdot 48$ & $18 \cdot 78$ & $358^{\mathrm{a}}$ & $3.78^{\mathrm{b}}$ & $19 \cdot 0^{\mathrm{a}}$ \\
\hline 175 & $1 \cdot 341$ & 20.09 & $19 \cdot 52$ & $378^{a b}$ & $3.62^{\mathrm{b}}$ & $19 \cdot 2^{\mathrm{a}}$ \\
\hline 156 & 1.349 & $20 \cdot 48$ & $19 \cdot 96$ & $405^{\mathrm{bc}}$ & $3.43^{\mathrm{ab}}$ & $20 \cdot 1^{\mathrm{ab}}$ \\
\hline 129 & $1 \cdot 321$ & $20 \cdot 39$ & $20 \cdot 06$ & $446^{d}$ & $3 \cdot 11^{\mathrm{a}}$ & $21 \cdot 9^{c}$ \\
\hline 101 & 1.269 & 20.00 & $19 \cdot 74$ & $427^{\mathrm{cd}}$ & $3 \cdot 10^{\mathrm{a}}$ & $21 \cdot 4^{\mathrm{bc}}$ \\
\hline & \multicolumn{5}{|c|}{ FL $\times$ ad libitum } & 0.64 \\
\hline 0.60 & 1.003 & $15 \cdot 54^{\mathrm{a}}$ & $15 \cdot 12^{\mathrm{a}}$ & $284^{\mathrm{a}}$ & $3 \cdot 63^{\mathrm{b}}$ & $18 \cdot 8^{a}$ \\
\hline 0.80 & 1.373 & $20 \cdot 74^{\mathrm{b}}$ & $20 \cdot 14^{\mathrm{b}}$ & $413^{\mathrm{b}}$ & $3.40^{\mathrm{ab}}$ & $20 \cdot 5^{\mathrm{b}}$ \\
\hline 0.95 & 1.602 & $24 \cdot 23^{c}$ & $23 \cdot 65^{c}$ & $506^{c}$ & $3 \cdot 20^{\mathrm{a}}$ & $21 \cdot 4^{\mathrm{b}}$ \\
\hline SE & 0.0198 & 0.241 & 0.236 & $8 \cdot 6$ & 0.104 & 0.95 \\
\hline \multicolumn{7}{|c|}{ Statistical significance of effect: } \\
\hline DPC & NS & NS & NS & $\star \star * *$ & ** & ** \\
\hline $\mathrm{FL}$ & 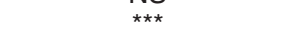 & $* \star *$ & 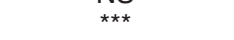 & 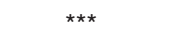 & * & 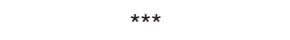 \\
\hline $\mathrm{DPC} \times \mathrm{FL}$ & NS & NS & NS & NS & NS & NS \\
\hline
\end{tabular}

DE, digestible energy; ME, metabolizable energy; DPC, dietary protein content; FL, feeding level.

$\mathrm{a}, \mathrm{b}, \mathrm{c}, \mathrm{d}$ Mean values within a column and within a treatment with unlike superscript letters were significantly different $(P<0.05)$

${ }^{\star} P<0.05,{ }^{\star \star} P<0.01,{ }^{\star \star \star} P<0.001$.

†For details of diets and procedures, see Tables 1 and 2 and p. 40.

Differences in energy intake amongst diets with different protein content were not significant.

Mean daily weight-gains are also shown in Table 3 . Highly significant effects of $\mathrm{CP}$ content in the diet and feeding level $(P<0.001)$ were observed. The interaction between both factors was not significant. Growth rate improved with each decrease in dietary CP from 192 up to $129 \mathrm{~g} / \mathrm{kg} \mathrm{DM}$ and then levelled off.

Food conversion ratios and growth rate/MJ ME were also significantly affected by the dietary $\mathrm{CP}$ content $(P<0.01)$ and feed intake $(P<0.05$ and $P<0.001$ respectively). The interactions were not significant. Food conversion and gain:ME intake ratios improved on decreasing the concentration of CP of the diet from 192 to $129 \mathrm{~g} / \mathrm{kg} \mathrm{DM}$ and were maintained thereafter. In addition, both variables improved on raising the level of feeding.

Linear regressions were established within diets to relate rate of gain $(\mathrm{g} / \mathrm{d})$ and ME intake. Diets $\mathrm{A}, \mathrm{B}, \mathrm{C}$ and $\mathrm{D}$ (see Table 2, p. 41) all have homogeneous regression coefficients; consequently, a composite regression was calculated on pooled data. The intercept of this overall regression did not differ significantly from zero and therefore the following highly significant $(P<0 \cdot 001)$ relationship was found:

$$
\begin{aligned}
\text { gain }(\mathrm{g} / \mathrm{d})= & 0.0197(\mathrm{SE} 0 \cdot 00035) \\
& \times \text { ME intake }(\mathrm{kJ} / \mathrm{d}), \quad n 47 .
\end{aligned}
$$

The regression coefficient indicates an increase of $19.7 \mathrm{~g}$ gain/MJ increase in $\mathrm{ME}$ intake, equivalent to an energy cost of $50.7 \mathrm{~kJ} \mathrm{ME} / \mathrm{g}$ gain.

The analysis of covariance revealed that the linear regressions plotted with data from diets that provided the lowest CP contents (diets E and F; see Table 2, p. 41) had similar slopes and a composite highly significant
$(P<0.001)$ regression was calculated:

$$
\begin{aligned}
\operatorname{gain}(\mathrm{g} / \mathrm{d})= & -182(\mathrm{SE} 35)+0 \cdot 031(\mathrm{SE} 0 \cdot 0017) \\
& \times \mathrm{ME} \text { intake }(\mathrm{kJ} / \mathrm{d}) ; n 24, \quad R^{2} 93.3 .
\end{aligned}
$$

From the slope of equation 2 an increase in daily gain of $31 \mathrm{~g} / \mathrm{MJ}$ increase in daily intake of ME is estimated, indicating that under conditions of optimal or suboptimal amino acid-N supply an average energy cost of $32.2 \mathrm{~kJ} \mathrm{ME} / \mathrm{g}$ gain can be expected. Therefore, it may be inferred that in the pig a surplus of dietary $\mathrm{CP}$ increases the energy cost of growth.

The protein content of the diet was negatively related to the digestibility and metabolizability of energy (Table 4). Decreasing the level of $\mathrm{CP}$ of the diet resulted in significant increases $(P<0.001)$ in DE:GE and ME:GE ratios, in part as an effect of the dilution of the high-protein diet with a protein-free mixture of high digestibility. The magnitude of the change was higher for the latter, so that the ME:DE ratio increased significantly $(P<0.001)$ from 0.961 to 0.987 on decreasing the dietary $\mathrm{CP}$ content from 223 to $101 \mathrm{~g} / \mathrm{kg} \mathrm{DM}$. On average, the energy density of the diets was in the range of 14.1 to $15.5 \mathrm{MJ} \mathrm{ME} / \mathrm{kg} \mathrm{DM}$ (see Table 2). The effect of changing the feeding level was only evident on the lowest allowance of feed, which resulted in the highest DE:GE and ME:GE ratios $(P<0 \cdot 05)$. On average ME:DE ratio was close to 0.97 whatever the feeding allowance.

The apparent digestibility of $\mathrm{CP}$ (apparent digestible $\mathrm{N}: \mathrm{N}$ intake) was not affected by the dietary CP content. However, it decreased on raising the level of feeding from 0.829 to $0.767(P<0.01)$. Both facts may indicate a comparatively lower capacity of this genotype for protein digestion. This variable was significantly influenced by the age of the animals $(P<0.001)$ and showed the lowest 
Table 4. The effects of protein content of the diet and level of feeding on the digestibility of energy and nitrogen and on protein deposition of growing lberian pigs between 15 and $50 \mathrm{~kg}$ live weight $†$

(Mean values for twelve pigs per dietary protein content group)

\begin{tabular}{|c|c|c|c|c|c|c|c|c|c|}
\hline & DE:GE & ME:GE & ME:DE & $\mathrm{NI}(\mathrm{g})$ & ApDN:NI & $\begin{array}{l}\text { Protein deposition } \\
(\mathrm{gRN} \times 6 \cdot 25 / \mathrm{d})\end{array}$ & $\mathrm{RN}: \mathrm{NI}$ & RN:ApDN & $\begin{array}{l}\text { Protein deposition } \\
\text { (g/MJ ME) }\end{array}$ \\
\hline \multicolumn{10}{|l|}{ DPC (g/kg DM) } \\
\hline 223 & $0.827^{a b}$ & $0.795^{a b}$ & $0.961^{\mathrm{a}}$ & $47 \cdot 77^{\mathrm{a}}$ & 0.809 & $47 \cdot 7^{\mathrm{ab}}$ & $0.159^{\mathrm{a}}$ & $0.197^{\mathrm{a}}$ & 2.40 \\
\hline 192 & $0.814^{\mathrm{a}}$ & $0.784^{a}$ & $0.964^{\mathrm{a}}$ & $40 \cdot 94^{\mathrm{b}}$ & 0.794 & $47 \cdot 9^{a}$ & $0.187^{\mathrm{ab}}$ & $0.236^{a b}$ & $2 \cdot 54$ \\
\hline 175 & $0.832^{\mathrm{ab}}$ & $0 \cdot 808^{\mathrm{bc}}$ & $0.971^{b}$ & $38.08^{c}$ & 0.790 & $49 \cdot 3^{a b}$ & $0.207^{b}$ & $0.264^{\mathrm{b}}$ & $2 \cdot 52$ \\
\hline 156 & $0 \cdot 845^{\mathrm{b}}$ & $0.824^{\mathrm{C}}$ & $0.974^{\mathrm{b}}$ & $33 \cdot 83^{d}$ & 0.781 & $53 \cdot 2^{\mathrm{bc}}$ & $0.253^{c}$ & $0.327^{c}$ & $2 \cdot 67$ \\
\hline 129 & $0.868^{c}$ & $0.854^{d}$ & $0.984^{c}$ & $27 \cdot 13^{\mathrm{e}}$ & 0.809 & $57 \cdot 4^{\mathrm{c}}$ & $0.334^{d}$ & $0.414^{d}$ & $2 \cdot 81$ \\
\hline 101 & $0.890^{d}$ & $0.878^{\mathrm{e}}$ & $0.987^{\mathrm{C}}$ & $20 \cdot 60^{f}$ & 0.794 & $51.9^{a b}$ & $0.402^{\mathrm{e}}$ & $0.507^{\mathrm{e}}$ & $2 \cdot 61$ \\
\hline SE & 0.0053 & 0.0053 & 0.0007 & $1 \cdot 140$ & 0.0080 & $1 \cdot 84$ & 0.0105 & 0.0126 & 0.106 \\
\hline \multicolumn{10}{|l|}{ FL $\times$ ad libitum } \\
\hline 0.60 & $0.859^{a}$ & $0.837^{a}$ & $0.973^{\mathrm{a}}$ & $26 \cdot 99^{a}$ & $0.829^{a}$ & $36 \cdot 7^{\mathrm{a}}$ & $0.241^{a}$ & $0.291^{a}$ & $2 \cdot 43^{\mathrm{a}}$ \\
\hline 0.80 & $0.839^{b}$ & $0 \cdot 815^{\mathrm{b}}$ & $0.971^{\mathrm{a}}$ & $35 \cdot 50^{\mathrm{b}}$ & $0.793^{b}$ & $51 \cdot 3^{\mathrm{b}}$ & $0.256^{\mathrm{ab}}$ & $0.323^{b}$ & $2 \cdot 55^{\mathrm{a}}$ \\
\hline 0.95 & $0.839^{b}$ & $0.820^{b}$ & $0.976^{\mathrm{b}}$ & $41 \cdot 69^{c}$ & $0.767^{b}$ & $65 \cdot 7^{c}$ & $0.274^{b}$ & $0.358^{\mathrm{C}}$ & $2 \cdot 79^{\mathrm{b}}$ \\
\hline SE & 0.0038 & 0.0038 & 0.0010 & 0.813 & 0.0057 & $1 \cdot 36$ & 0.0078 & 0.0094 & 0.078 \\
\hline \multicolumn{10}{|l|}{ Age (d) } \\
\hline $68-82$ & 0.835 & 0.815 & $0.976^{\mathrm{a}}$ & $21 \cdot 6^{\mathrm{a}}$ & $0.767^{\mathrm{a}}$ & & & & \\
\hline $93-107$ & 0.843 & 0.819 & $0.971^{\mathrm{b}}$ & $34 \cdot 2^{b}$ & $0 \cdot 802^{b}$ & & & & \\
\hline$>120$ & 0.849 & 0.826 & $0.972^{b}$ & $46 \cdot 6^{c}$ & $0.808^{b}$ & & & & \\
\hline SE & 0.0038 & 0.0038 & 0.0010 & $1 \cdot 140$ & 0.0057 & & & & \\
\hline \multicolumn{10}{|c|}{ Statistical significance of effect: } \\
\hline DPC & 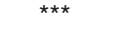 & $\star \star \star *$ & $\star \star * *$ & $\star \star * *$ & NS & $\star \star *$ & $* * *$ & *** & NS \\
\hline FL & * & * & $\star *$ & $\star \star \star \star ~$ & $\star \star *$ & $\star \star \star \star ~$ & $\star \star$ & $\star \star \star \star ~$ & $\star *$ \\
\hline Age & NS & NS & ** & $* \star \star$ & $\star \star \star *$ & & & & \\
\hline $\mathrm{DPC} \times \mathrm{FL}$ & NS & NS & NS & NS & NS & NS & NS & NS & NS \\
\hline DPC $\times$ age & NS & NS & NS & NS & NS & & & & \\
\hline FL $\times$ age & NS & NS & NS & NS & NS & & & & \\
\hline $\mathrm{DPC} \times \mathrm{FL} \times$ age & NS & NS & NS & NS & NS & & & & \\
\hline
\end{tabular}

$\mathrm{DE}$, digestible energy; GE, gross energy; ME, metabolizable energy; NI, nitrogen intake; ApDN, apparent digestible nitrogen; RN, retained nitrogen; DPC, dietary protein content; FL, feeding level.

$\mathrm{a}, \mathrm{b}, \mathrm{c}, \mathrm{d}, \mathrm{e}, \mathrm{f}$ Mean values within a column and within a treatment with unlike superscript letters were significantly different $(P<0 \cdot 05)$.

${ }^{\star} P<0.05,{ }^{\star \star} P<0.01,{ }^{\star \star \star} P<0.001$.

†For details of diets and procedures, see Tables 1 and 2 and p. 40.

value (0.767) when measured in pigs of $68-82 \mathrm{~d}$ of age and a constant value in older animals (0.802-0.808).

The average rate of PD is also shown in Table 4. PD increased significantly $(P<0.01)$ with each decrease in dietary $\mathrm{CP}$ content and reached a maximum value when the diet providing $129 \mathrm{~g} \mathrm{CP} / \mathrm{kg} \mathrm{DM}$ was offered except for the lowest feeding level assayed. The effect of feeding level on the rate of PD was positive and highly significant $(P<0.001)$. The efficiencies of utilization of total $\mathrm{N}$ (retained $\mathrm{N}: \mathrm{N}$ intake) and $\mathrm{N}$ apparently absorbed (retained $\mathrm{N}$ :apparent digestible $\mathrm{N}$ ) improved with declining $\mathrm{CP}$ concentration in the diet $(P<0 \cdot 001)$ and also with increasing feed allowance $(P<0.01$ and $P<0.001$ respectively). Interaction between factors was always not significant. Highly significant $(P<0.010-0.001)$ linear regression equations relating daily $\mathrm{N}$ retention $\left(\mathrm{g} / \mathrm{kg} \mathrm{BW}^{0.75}\right.$ per d) and $\mathrm{N}$ intake $\left(\mathrm{g} / \mathrm{kg} \mathrm{BW}^{0.75}\right.$ per d) or apparently digestible $\mathrm{N}$ intake $\left(\mathrm{g} / \mathrm{kg} \mathrm{BW}^{0.75}\right.$ per $\left.\mathrm{d}\right)$ were obtained. These regressions have intercept terms not significantly different from zero, except for the diet providing $129 \mathrm{~g} \mathrm{CP} / \mathrm{kg} \mathrm{DM}$. For this diet the following regressions were obtained:

$$
\begin{aligned}
\text { retained } \mathrm{N}= & -0.196(\mathrm{SE} 0.087) \\
& +0.447(\mathrm{SE} 0.042) \mathrm{N} \text { intake; } n 12, R^{2} 92 \cdot 0,
\end{aligned}
$$

and

$$
\begin{aligned}
\text { retained } \mathrm{N}= & -0.291(\mathrm{SE} 0.098) \\
& +0.603(\mathrm{SE} 0.088) \text { digestible } \mathrm{N} ; n 12, R^{2} 81 \cdot 0 .
\end{aligned}
$$

Equation 3 estimates daily $\mathrm{N}$ endogenous losses as $196 \mathrm{mg} / \mathrm{kg} \mathrm{BW}^{0.75}$ and predicts $\mathrm{N}$ maintenance requirements as $438 \mathrm{mg} / \mathrm{kg} \mathrm{BW}^{0.75}$. Equation 4 indicates that daily endogenous $\mathrm{N}$ losses attain $0.291 \mathrm{~g} / \mathrm{kg} \mathrm{BW}^{0.75}$ and estimates an increase in daily protein deposition of $0.603 \mathrm{~g} / \mathrm{g}$ increase in intake of apparently digestible ideal protein.

PD ranged between 2.40 and $2.81 \mathrm{~g} / \mathrm{MJME}$ intake. Although this relationship showed a tendency to improve with decreasing dietary $\mathrm{N}$ supply, it was not significantly affected by the $\mathrm{CP}$ content of the diet, but was positively related with feeding level $(P<0 \cdot 01)$.

Mean values of energy retention and their partition into protein and fat deposition are presented in Table 5 and in Fig. 1. The results have been expressed both in $\mathrm{kJ} / \mathrm{d}$ and $\mathrm{kJ} / \mathrm{kg} \mathrm{BW}^{0.75}$ per $\mathrm{d}$, the latter being calculated from the mean live $\mathrm{BW}$ of each pig for the whole experimental period. Interactions between factors were always not significant. The empty BW:live BW was not affected by experimental treatments and attained a mean value of 


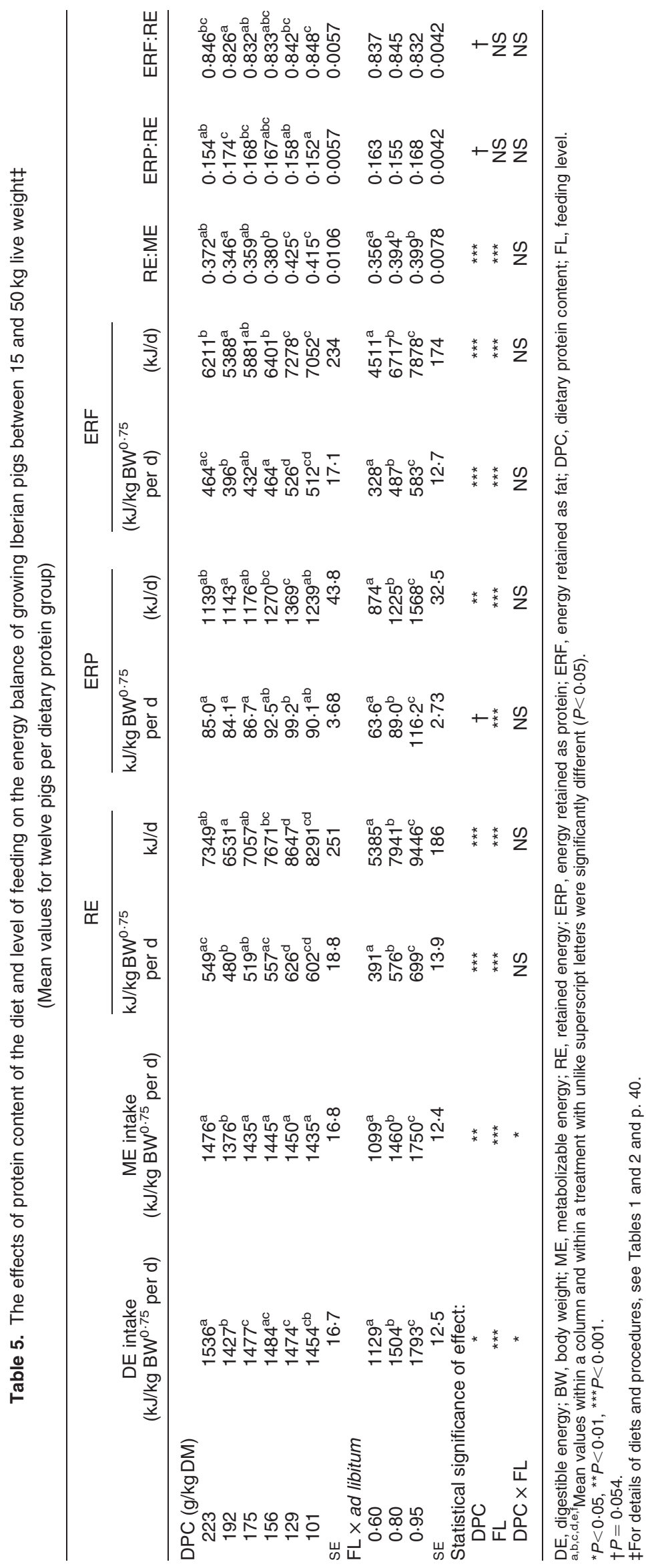




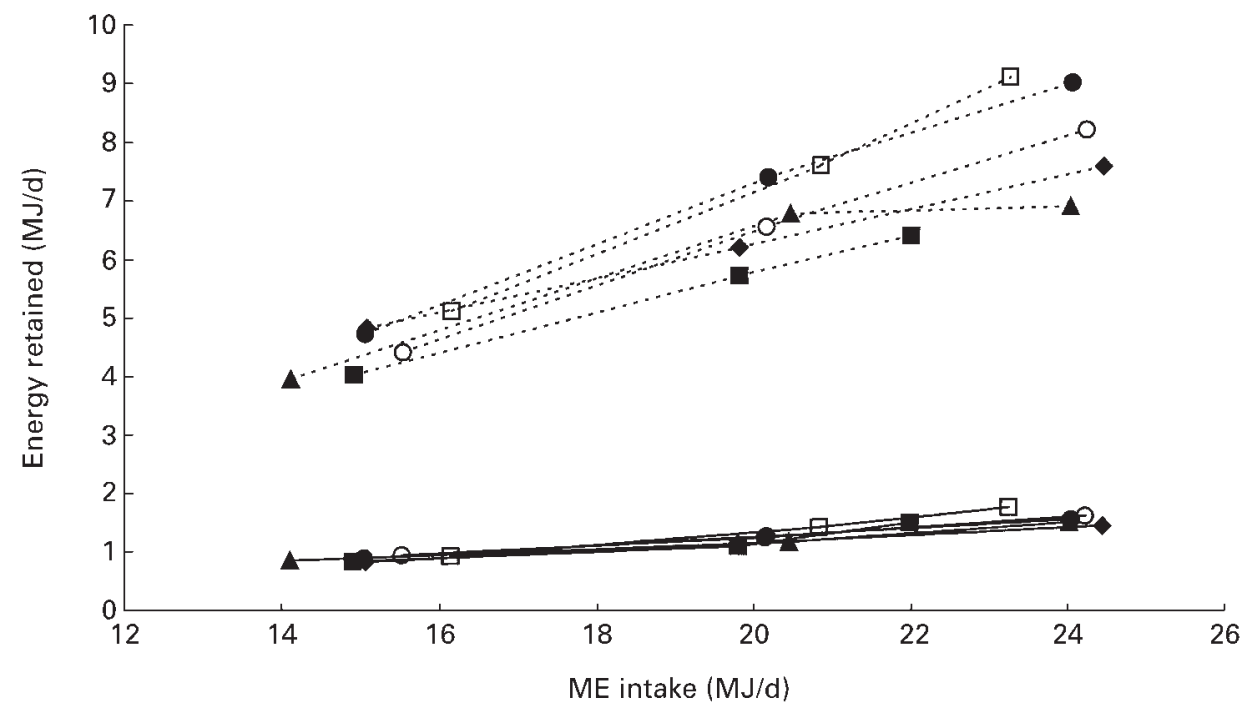

Fig. 1. The relationship between metabolizable energy (ME) intake and energy retained as protein (-) and energy retained as fat (-----) obtained in growing lberian pigs (15-50 kg live weight; twelve per protein dietary group) fed six isoenergetic diets varying in protein content. ४, $223 \mathrm{~g}$ crude protein $(\mathrm{N} \times 6 \cdot 25) / \mathrm{kg} \mathrm{DM} ; \mathbf{\square}, 193 \mathrm{~g}$ crude protein $/ \mathrm{kg} \mathrm{DM;} \mathbf{\Delta}, 175 \mathrm{~g}$ crude protein $/ \mathrm{kg} \mathrm{DM;} \bigcirc, 156 \mathrm{~g} \mathrm{CP} / \mathrm{kg} \mathrm{DM;} \square, 129 \mathrm{~g} \mathrm{crude}$ protein $/ \mathrm{kg} \mathrm{DM;}, 101 \mathrm{~g}$ crude protein $/ \mathrm{kg}$ DM. For details of diets and procedures, see Tables 1 and 2 and p. 40.

0.968 (SE 0.0011). Retained energy (RE) increased significantly $(P<0.001)$ from 480 to $626 \mathrm{~kJ} / \mathrm{kg} \mathrm{BW}^{0.75}$ with each decrease in CP content of the diet from 192 to $129 \mathrm{~g} / \mathrm{kg} \mathrm{DM}$ and was maintained thereafter. Raising the level of intake of the diets resulted in significant linear increases in $\mathrm{RE}$ irrespective of the diet fed $(P<0 \cdot 001)$. As mentioned earlier, PD, here expressed as energy retained as protein, was inversely related to the protein content of the diet, with a maximum value of $99 \mathrm{~kJ} / \mathrm{kg} \mathrm{BW}^{0 \cdot 75}$ for the diet containing $129 \mathrm{~g} \mathrm{CP} / \mathrm{kg} \mathrm{DM}$, and increased significantly with feeding level. Fat deposition paralleled RE; it increased on raising feed intake and on decreasing dietary $\mathrm{CP}$ content from 192 to $129 \mathrm{~g} / \mathrm{kg}$ DM. On average it accounted for 0.838 (SE 0.0039) of total energy retained. The overall efficiency of utilization of $\mathrm{ME}$ for energy gain (RE:ME) improved significantly $(P<0.001)$ from 0.346 to 0.425 with each decrease in dietary CP content from 192 to $129 \mathrm{~g} / \mathrm{kg} \mathrm{DM}$ and levelled off thereafter. It was positively affected by feeding level $(P<0 \cdot 001)$, although it remained constant with the two highest intakes assayed.

Total RE (kJ/kg BW ${ }^{0.75}$ per d) was related to ME intake $\left(\mathrm{kJ} / \mathrm{kg} \mathrm{BW}^{0.75}\right.$ per $\left.\mathrm{d}\right)$ by means of linear regression equations to predict maintenance requirements and calculate net efficiencies of energy utilization in the growing animal. Separate regressions were calculated within dietary protein contents. Diets A, B and C, which provided amounts of amino acid-N far greater than needed to support maximum protein retention, showed similar regression coefficients and intercept values not different from zero. A composite regression was established:

$$
\mathrm{RE}=0.360(\operatorname{sE} 0 \cdot 007) \times \mathrm{ME} \text { intake; } n 35,
$$

indicating that a considerable excess of protein content in the diet fed $(223-175 \mathrm{~g} / \mathrm{kg} \mathrm{DM})$ resulted in a low overall efficiency of utilization of dietary energy for growth $(0 \cdot 360)$. Similarly, the covariance analysis indicated that the regression coefficients of the equations derived for diets D, E and F were homogeneous and a pooled equation was calculated accordingly:

$$
\begin{aligned}
\mathrm{RE}= & -246 \text { (SE 49) } \\
& +0.582(\mathrm{SE} 0.034) \mathrm{ME} \text { intake; } n \text { 36, } R^{2} \text { 88.9. }
\end{aligned}
$$

This equation estimates ME requirements for maintenance as $422 \mathrm{~kJ} / \mathrm{kg} \mathrm{BW}^{0.75}$ per d. Table 6 gives specific information on live-weight gain, protein utilization and RE for each of the eighteen treatments assayed. The average rates of $\mathrm{PD}$, fat, ash and water in the empty body of the Iberian pigs growing from 15 to $50 \mathrm{~kg}$ live weight is presented in Table 7. While the level of feeding affected positively and significantly $(P<0.001)$ the rate of gain of all the components measured, only the rates of deposition of body fat and protein showed a significant $(P<0 \cdot 01$ and $P<0.001$ respectively) tendency to increase with each decrease in dietary protein concentration from 192 to $129 \mathrm{~g} / \mathrm{kg} \mathrm{DM}$ and declined thereafter. The mean wholebody chemical composition of the reference initial group was $153.0,167 \cdot 0,38.6$ and $642.0 \mathrm{~g} / \mathrm{kg} \mathrm{CP}$, fat, ash and water respectively. Between 15 and $50 \mathrm{~kg}$, the mean chemical composition of $1 \mathrm{~kg}$ gain was $128 \cdot 0,396 \cdot 0,26 \cdot 3$ and $439.0 \mathrm{~g} \mathrm{CP}$, fat, ash and water respectively. Whole-body chemical composition at approximately $50 \mathrm{~kg}$ empty BW was, on average, $138 \cdot 0,327 \cdot 0,32.2$ and $503.0 \mathrm{~g}$ for $\mathrm{CP}$, fat, ash and water $/ \mathrm{kg}$ respectively. These results underline the lipogenic profile of this breed.

\section{Discussion}

A great deal of information is now available on the interactions of energy and protein intakes in the growing pig. Part of this information derives from studies made with modern strains of pigs of high genetic potential. For 
these animals, energy intake seems to be a limiting dietary factor and, in the young animal, the major constraint on growth (Close et al. 1979; Campbell \& Dunkin, 1983a,b; Rao \& McCracken, 1991, 1992). The results suggest that the selection has raised the genetic capacity of these pigs for lean gain beyond the upper limit of appetite. For strains with a moderate potential for protein accretion there is ample information to accept that PD follows a linear-plateau model: the rate of protein accretion depends on the ideal protein supply up to some breakpoint beyond which protein retention depends on energy supply (Whittemore \& Fawcett, 1976; Schneider et al. 1982; Campbell et al. 1984, 1985; Dunkin et al. 1986; Kyriazakis \& Emmans, 1992).

The design of the present experiment allows us to ascertain the relationship between feed intake and PD at different protein:energy ratios, as the range of planned feeding levels was wide and its upper limit approached ad libitum intakes. Expressed on a metabolic BW basis, average ME intakes were 1099,1460 and $1750 \mathrm{~kJ} / \mathrm{kg} \mathrm{BW}^{0.75}$ per d respectively for $0.60,0.80$ and $0.95 \times$ ad libitum level of feeding. Taking into account present estimates for $\mathrm{ME}$ for maintenance $\left(422 \mathrm{~kJ} / \mathrm{kg} \mathrm{BW}^{0.75}\right.$ per d) the feeding levels planned for this study provided 2.6-, 3.5- and 4.1fold the maintenance energy requirements. In the present experiment, the mean supply of digestible ideal protein was in the range of 12.2 to $5 \cdot 16 \mathrm{~g} / \mathrm{MJ} \mathrm{ME}$ according to the diet offered. Most of the diets contained an excess of protein relative to energy. This was not expected when the experiment was designed, as a somewhat higher potential for protein accretion was anticipated in the Iberian pig. In fact it was observed that only one of the diets offered was marginally deficient in protein. This fact adds some difficulties in the interpretation of the experimental results. Intakes of $\mathrm{CP}$ greater than that needed to support maximum protein accretion are known to result in decreases in the rate and efficiency of growth (Carr et al. 1977), as was observed in the present experiment (Table 3).

The values for the average rate of gain and of PD found in the present study $(284-506,36 \cdot 7-65 \cdot 7 \mathrm{~g} / \mathrm{d}$ respectively) are low in comparison with published results from experiments carried out with modern strains of pigs at a similar stage of growth (Kyriazakis \& Emmans, 1992; Campbell \& Taverner, 1988; Fuller et al. 1995).

The low potential of the Iberian pig for growth and lean tissue deposition should be related to the poor efficiency of utilization of the dietary protein observed (Table 4). The rate of growth and protein accretion depended on feeding level even with diets providing a surplus of digestible ideal protein (Tables 3, 4 and 6), but the efficiency with which protein was retained was inversely related to protein:energy ratio, implying that the beneficial effect of an increase in ME intake on rate of growth and PD was modified by an inadequate protein supply. Tables 4 and 6 indicate that at fixed energy intakes the gross efficiency with which protein was used for PD (retained $\mathrm{N}: \mathrm{N}$ intake) varied inversely with protein supply, in agreement with previous reports (Berschauer et al. 1983; Kyriazakis et al. 1994). In the present experiment, values for the gross efficiency of protein utilization observed when the

Table 6. The effects of protein content of the diet and level of feeding on the average rate of live weight gain, protein deposition and total energy retention of Iberian pigs growing between 15 and $50 \mathrm{~kg}$ live weight $†$

(Mean values for twelve pigs per dietary protein group)

\begin{tabular}{|c|c|c|c|c|c|c|c|}
\hline & $\begin{array}{c}\text { DPC } \\
\text { (g/kg DM) }\end{array}$ & $\begin{array}{l}\text { DP:ME } \\
\text { (g/MJ) }\end{array}$ & $\begin{array}{l}\text { ME intake } \\
(\mathrm{kJ} / \mathrm{d})\end{array}$ & $\begin{array}{l}\text { Live-weight gain } \\
\qquad(\mathrm{g} / \mathrm{d})\end{array}$ & $\begin{array}{l}\text { Protein deposition } \\
\qquad(\mathrm{g} / \mathrm{d})\end{array}$ & $\mathrm{RN}: \mathrm{NI}$ & $\begin{array}{l}\text { Total energy retention } \\
(\mathrm{kJ} / \mathrm{d})\end{array}$ \\
\hline \multicolumn{8}{|c|}{$\mathrm{FL} \times$ ad libitum } \\
\hline \multirow[t]{6}{*}{0.60} & 223 & $12 \cdot 35$ & 15059 & 293 & $34 \cdot 7$ & 0.157 & 5654 \\
\hline & 192 & 11.46 & 14897 & 261 & $34 \cdot 7$ & 0.173 & 4852 \\
\hline & 175 & $10 \cdot 19$ & 14097 & 261 & 35.4 & 0.204 & 4793 \\
\hline & 156 & 8.70 & 15515 & 288 & 39.4 & 0.246 & 5358 \\
\hline & 129 & 7.03 & 16129 & 304 & 38.6 & 0.283 & 6038 \\
\hline & 101 & $5 \cdot 19$ & 15039 & 297 & $37 \cdot 2$ & 0.387 & 5617 \\
\hline \multirow[t]{6}{*}{0.80} & 223 & $12 \cdot 47$ & 19794 & 400 & $47 \cdot 7$ & 0.155 & 7347 \\
\hline & 192 & $10 \cdot 74$ & 19467 & 359 & $46 \cdot 0$ & 0.175 & 6827 \\
\hline & 175 & 9.54 & 20441 & 403 & $49 \cdot 1$ & 0.198 & 7956 \\
\hline & 156 & $8 \cdot 38$ & 20137 & 405 & 52.4 & 0.247 & 7813 \\
\hline & 129 & $6 \cdot 63$ & 20827 & 474 & $59 \cdot 6$ & 0.344 & 9027 \\
\hline & 101 & 4.98 & 20156 & 440 & $53 \cdot 3$ & 0.418 & 8679 \\
\hline \multirow[t]{6}{*}{0.95} & 223 & 11.75 & 24435 & 489 & $60 \cdot 8$ & 0.165 & 9047 \\
\hline & 192 & $10 \cdot 30$ & 21979 & 453 & $63 \cdot 0$ & 0.211 & 7914 \\
\hline & 175 & $9 \cdot 16$ & 24012 & 469 & 63.4 & 0.219 & 8422 \\
\hline & 156 & 7.63 & 24216 & 522 & $67 \cdot 9$ & 0.266 & 9841 \\
\hline & 129 & 6.93 & 23236 & 559 & 74.0 & 0.370 & 10875 \\
\hline & 101 & $5 \cdot 31$ & 24034 & 544 & 65.4 & 0.402 & 10578 \\
\hline SE & & & 550 & $20 \cdot 1$ & $3 \cdot 18$ & 0.0182 & 434 \\
\hline \multicolumn{8}{|c|}{ Statistical significance of effect: } \\
\hline \multicolumn{3}{|c|}{ DPC } & NS & $\star * *$ & ** & *** & *** \\
\hline & $\star \star \star *$ & $\star \star * *$ & $\star \star \star *$ & * & $* \star \star *$ \\
\hline \multicolumn{3}{|l|}{$\mathrm{DPC} \times \mathrm{FL}$} & NS & NS & NS & NS & NS \\
\hline
\end{tabular}

DPC, dietary protein content; DP, digestible ideal protein; ME, metabolizable energy; RN, retained nitrogen; NI, nitrogen intake.

${ }^{*} P<0.05,{ }^{* *} P<0.01,{ }^{* \star *} P<0.001$.

†For details of diets and procedures, see Tables 1 and 2 and p. 40. 
Table 7. The effects of protein content of the diet and level of feeding on the rates of deposition of water, protein, fat and ash $(\mathrm{g} / \mathrm{d})$ in the empty body of Iberian pigs growing between 15 and $50 \mathrm{~kg}$ live weight†

(Mean values for twelve pigs per dietary protein group)

\begin{tabular}{|c|c|c|c|c|}
\hline & Water & Protein & Fat & Ash \\
\hline \multicolumn{5}{|c|}{ DPC (g/kg DM) } \\
\hline 223 & 175 & $47 \cdot 7^{\mathrm{ab}}$ & $156^{\mathrm{b}}$ & $10 \cdot 8$ \\
\hline 192 & 163 & $47 \cdot 9^{\mathrm{a}}$ & $136^{\mathrm{a}}$ & 11.9 \\
\hline 175 & 168 & $49 \cdot 3^{\mathrm{ab}}$ & $148^{a b}$ & $12 \cdot 1$ \\
\hline 156 & 177 & $53 \cdot 2^{\mathrm{bc}}$ & $161^{\mathrm{b}}$ & $11 \cdot 8$ \\
\hline 129 & 186 & $57 \cdot 4^{\mathrm{C}}$ & $183^{\mathrm{C}}$ & 11.4 \\
\hline 101 & 177 & $51.9^{a b}$ & $177^{\mathrm{C}}$ & $10 \cdot 8$ \\
\hline SE & $7 \cdot 1$ & 1.84 & 5.9 & 0.57 \\
\hline \multicolumn{5}{|c|}{ FL $\times$ ad libitum } \\
\hline 0.60 & $122^{a}$ & $36 \cdot 7^{a}$ & $113^{\mathrm{a}}$ & $8 \cdot 19^{a}$ \\
\hline 0.80 & $177^{\mathrm{b}}$ & $51 \cdot 3^{b}$ & $169^{b}$ & $12 \cdot 2^{\mathrm{b}}$ \\
\hline 0.95 & $225^{c}$ & $65 \cdot 7^{\mathrm{c}}$ & $198^{C}$ & $14 \cdot 6^{c}$ \\
\hline SE & $5 \cdot 3$ & 1.36 & 4.4 & 0.42 \\
\hline \multicolumn{5}{|c|}{ Statistical significance of effect: } \\
\hline DPC & NS & $\star \star *$ & 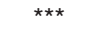 & NS \\
\hline $\mathrm{FL}$ & $* \star *$ & $\star \star \star *$ & *** & $\star \star * *$ \\
\hline $\mathrm{DPC} \times \mathrm{FL}$ & NS & NS & NS & NS \\
\hline
\end{tabular}

DPC, dietary protein content; FL, feeding level.

${ }^{a, b, c}$ Mean values within a column and within a treatment with unlike superscript letters were significantly different $(P<0.05)$.

†For details of diets and procedures, see Tables 1 and 2 and p. 40

${ }^{\star \star} P<0.01,{ }^{* \star \star} P<0.001$.

diets providing $156-101 \mathrm{~g} \mathrm{CP} / \mathrm{kg} \mathrm{DM}$ were assayed at intakes close to ad libitum were in the range of 0.266 to 0.402 and, therefore, are lower than values which can be calculated for the Chinese Meishan pigs given, at the same level of feeding, feed mixtures containing 142 or $121 \mathrm{~g} \mathrm{CP} / \mathrm{kg} \mathrm{DM}$ (0.425 and 0.444; Kyriazakis et al. 1994).

Table 6 clearly shows that both treatment factors were independent in their effects on the rates of gain, PD or RE. Maximum values were attained when the diet containing $129 \mathrm{~g} \mathrm{CP} / \mathrm{kg}$ DM was fed. This diet provided on average $6.86 \mathrm{~g}$ digestible ideal protein/MJ ME. With this diet the mean PD reached $74.0 \mathrm{~g}$, the maximum value attainable by the Iberian pig. This feeding regimen resulted in average values for live-weight gain and RE of $559 \mathrm{~g} / \mathrm{d}$ and $10.9 \mathrm{MJ} / \mathrm{d}$ respectively. However, it should be pointed out that this value of $74 \mathrm{~g} / \mathrm{d}$ may slightly underestimate the maximum attainable PD as most of the pigs on the highest level of feeding had energy supplies which were in fact close to but not sufficient for ad libitum intakes. Probably the best model to describe the relationship between protein content and protein accretion would be a linear-plateau model. However, a definite conclusion in this respect would have required additional data from lower-protein diets. The maximum value for PD in the Iberian pig is far lower than values found in modern pig genotypes at various stages of growth (Schneider et al. 1982; Campbell et al. 1985; Dunkin et al. 1986; Campbell \& Taverner, 1988). Iberian pigs seem to have slower growth rates and a lower capacity for protein accretion at feeding intakes close to ad libitum than Chinese Meishan pigs (Kyriazakis et al. 1993).

The value obtained by equation 3 for daily $\mathrm{N}$ endogenous losses $\left(196 \mathrm{mg} / \mathrm{kg} \mathrm{BW}^{0 \cdot 75}\right)$ is higher than those of 150 and
$246 \mathrm{mg} / \mathrm{kg} \mathrm{BW} \mathrm{BW}^{0.75}$ proposed by Carr et al. (1977), the former obtained with very-low-protein diets, the latter from experiments in which protein quality and energy intake were judged adequate for pigs of a range of $\mathrm{BW}$. The intercept of equation 4 estimates daily endogenous $\mathrm{N}$ losses as $0.291 \mathrm{~g} / \mathrm{kg} \mathrm{BW}^{0.75}$, a value somewhat higher than the mean estimate $\left(0.255 \mathrm{~g} / \mathrm{kg} \mathrm{BW}^{0.75}\right.$ per $\left.\mathrm{d}\right)$ reported by Berschauer et al. (1983). The value of $0.483 \mathrm{~g}$ digestible $\mathrm{N} / \mathrm{kg} \mathrm{BW}^{0.75}$ calculated for $\mathrm{N}$ for maintenance by equation 4 is greater than the mean value of $0.307 \mathrm{~g} / \mathrm{kg} \mathrm{BW}^{0.75}$ per $\mathrm{d}$ published by Berschauer et al. (1983).

Our estimate of $422 \mathrm{~kJ} / \mathrm{kg} \mathrm{BW}^{0 \cdot 75}$ per d for ME requirements for maintenance calculated by equation 6 is slightly lower than the preferred estimate of $458 \mathrm{~kJ} / \mathrm{kg} \mathrm{BW}^{0.75}$ per d by the Agricultural Research Council (1981) or the mean value of $443 \mathrm{~kJ} / \mathrm{kg} \mathrm{BW}^{0.75}$ per d reported by the National Research Council (1998) or the common estimate of $469 \mathrm{~kJ} / \mathrm{kg} \mathrm{BW}^{0 \cdot 75}$ per d reported by Noblet et al. (1989) for growing boars, barrows and gilts. The value obtained in the present study for ME for maintenance seems to be reasonable for a strain with a low potential for protein accretion, which results in a low-body protein content. Campbell \& Taverner (1988) reported higher energy requirements for maintenance as an effect of genetic improvement in PD. Our estimate for the net efficiency of use of $\mathrm{ME}$ for growth $\left(\mathrm{K}_{\mathrm{w}}\right)$ is unexpectedly low taking into account the low protein:fat ratio observed in the energy gain and similar to those reported by Susenbeth \& Menke (1991) and McCracken et al. (1994) for pigs with a high potential for protein accretion. We do not have a satisfactory explanation for the low coefficient obtained. The Agricultural Research Council (1981) reported values for $\mathrm{k}_{\mathrm{W}}$ in the range of 0.64 to 0.76 from experiments in pigs in stages of growth within 20 and $70 \mathrm{~kg} \mathrm{BW}$.

In the present experiment, the relative proportion of PD and fat deposition expressed in energy terms were on average 0.162 and 0.838 respectively, close to that found by Noblet et al. (1999) in Meishan castrates. Therefore, the contribution of fat to total energy retention observed in the present study was comparatively higher than that found in modern pig genotypes under normal feeding conditions (Close et al. 1983; Campbell et al. 1985; Kyriazakis \& Emmans, 1992; Fuller et al. 1995). In this situation, one would expect high values for the net efficiency with which the feed energy is used for energy retention. This was not the case. The energy retained as fat showed a slight tendency to increase relative to the energy retained as protein with each decrease in the protein content of the diet from a surplus to an adequate $\mathrm{N}$ supply. This would explain the comparatively lower values observed for the overall efficiency of utilization of ME for energy gain (RE:ME; Table 5) when the diets which provided greater amounts of ideal protein were offered.

Estimates of the partial efficiencies of ME utilization for protein deposition $\left(\mathrm{k}_{\mathrm{p}}\right)$ and fat deposition $\left(\mathrm{k}_{\mathrm{f}}\right)$ were calculated by means of a multiple regression equation (Kielanowski, 1965) using ME intake $\left(\mathrm{kJ} / \mathrm{kg} \mathrm{BW}^{0.75}\right.$ per d) as dependent variable and energy retained as protein $\left(\mathrm{kJ} / \mathrm{kg} \mathrm{BW}^{0.75}\right.$ per d) and as fat $\left(\mathrm{kJ} / \mathrm{kg} \mathrm{BW}^{0.75}\right.$ per d) as independent variables. Highly significant equations 
$(P<0 \cdot 001)$ were derived:

$$
\begin{aligned}
\mathrm{ME} \text { intake }= & 376(\mathrm{SE} 94)+4.66(\mathrm{SE} 1.53) \mathrm{ERP} \\
& +1.53(\mathrm{SE} 0.35) \mathrm{ERF} ; n 35, \mathrm{R}^{2} 81.2,
\end{aligned}
$$

obtained when diets $\mathrm{A}, \mathrm{B}$ and $\mathrm{C}$, were fed and

$$
\begin{aligned}
\mathrm{ME} \text { intake }= & 516(\mathrm{SE} 54)+3.30(\mathrm{SE} 1.07) \text { ERP } \\
& +1.23(\mathrm{SE} 0.20) \mathrm{ERF} ; n \text { 36, } R^{2} \text { 89.2, }
\end{aligned}
$$

calculated for diets D, E and F, where ERP is energy retained as protein and ERF is energy retained as fat.

Equation 7 estimates ME for maintenance as $376 \mathrm{~kJ} /$ $\mathrm{kg} \mathrm{BW}^{0.75}$ per $\mathrm{d}$ and $\mathrm{k}_{\mathrm{p}}$ and $\mathrm{k}_{\mathrm{f}}$ as $1 / 4.66=0.215$ and $1 / 1.53=0.653$ respectively. From the coefficients of the energy retained as protein and as fat, energy costs of 111 and $60 \mathrm{kJME} / \mathrm{g}$ protein and fat accretion are calculated respectively. Equation 8 predicts $\mathrm{ME}$ for maintenance as $516 \mathrm{~kJ} / \mathrm{kg} \mathrm{BW}^{0.75}$ per $\mathrm{d}$ and $\mathrm{k}_{\mathrm{p}}$ and $\mathrm{k}_{\mathrm{f}}$ as $1 / 3.30=0.303$ and $1 / 1.23=0.812$ respectively, indicating that the ME costs for protein accretion and fat deposition attain 79 and $48 \mathrm{~kJ} / \mathrm{g}$ respectively. The model overestimates maintenance energy requirements in comparison with equation 6 , but predicts the response of the growing Iberian pig to energy input in terms of protein and lipid retention. Most of the values obtained for $\mathrm{k}_{\mathrm{p}}$ in the growing pig following this model fall in the range of 0.57 to 0.36 (Fowler, 1978), while estimates of $k_{f}$ lay between 0.77 and 0.70 . Our estimates for $k_{p}$ and $k_{f}$ are out of these ranges. Preferred estimates for $\mathrm{k}_{\mathrm{p}}$ and $\mathrm{k}_{\mathrm{f}}$ of the Agricultural Research Council (1981) are 0.56 and 0.74, while the National Research Council (1998) assumes a mean energy cost for protein retention of $44.35 \mathrm{MJ}(10.6 \mathrm{Mcal}) \mathrm{ME} / \mathrm{kg}$ protein, equivalent to a mean value for $\mathrm{k}_{\mathrm{p}}$ of 0.54 , and a mean energy cost for fat deposition of $51.88 \mathrm{MJ}(12.5 \mathrm{Mcal}) \mathrm{ME} / \mathrm{kg}$ fat, indicating a mean value of $\mathrm{k}_{\mathrm{f}}$ of 0.76 . Although the problem of colinearity and interdependence of the regression coefficients for PD and fat deposition cannot be overlooked, our results would indicate higher partial efficiencies of utilization of ME for both PD and fat deposition when the dietary supply of protein is close to requirements. The energy cost involved in urea synthesis to get rid of the excess of amino acid- $\mathrm{N}$ might have contributed to the comparatively higher energy cost of PD when diets with the highest protein contents were fed.

In the present experiment, at $50 \mathrm{~kg} \mathrm{BW}$ the empty body of the Iberian pig contained on average 138 and $327 \mathrm{~g}$ protein and fat $/ \mathrm{kg}$ respectively. Gains of 128.0 and 396.0 protein and fat $/ \mathrm{kg}$ respectively were deposited on average in the growing animal from 15 to $50 \mathrm{~kg} \mathrm{BW}$. Therefore, in marked contrast to modern highly improved pig breeds selected for a high rate of growth and low level of fatness, the Iberian pig should be considered as a lipogenic breed with a slow rate of growth. Taking into account the partial regression coefficients of equation 8 and the average composition of gain, $29.1 \mathrm{MJME} / \mathrm{kg}$ increase in body gain would be needed.
In agreement with previous reports, the present results confirm the suggestion of a marked effect of genotype on protein and energy metabolism of the growing pig and give support to the need for each particular population of animals of describing the response of body protein accretion to energy intake. Then an appropriate balance can be established between the protein content of the diet and energy supply. The information is extremely valuable to define feeding strategies economically optimal and environmentally acceptable.

\section{Acknowledgements}

This study was supported by CICYT grant No. AGF961364. We thank Mrs Encarnación Colmenero and $\mathrm{Mr}$ Francisco Funes for skilful technical assistance and Sánchez Romero Carvajal Jabugo S.A. (Seville) and Sucesores de Miguel Vilchez Riquelme S.A. (Granada) for their helpful collaboration.

\section{References}

Agricultural Research Council (1981) The Nutrient Requirements of Pigs. Slough: Commonwealth Agricultural Bureaux.

Association of Official Analytical Chemists (1975) Official Methods of Analysis of the Association of Official Analytical Chemists, 12th ed. Washington, DC: AOAC.

Berschauer F, Close WH \& Stephens DB (1983) The influence of protein:energy value of the ration and level of feed intake on the energy and nitrogen metabolism of the growing pig. 2 . Nitrogen metabolism at two environmental temperatures. British Journal of Nutrition 49, 271-283.

Campbell RG \& Dunkin AC (1983a) The effects of energy intake and dietary protein on nitrogen retention, growth performance, body composition and some aspects of energy metabolism of baby pigs. British Journal of Nutrition 49, 221-230.

Campbell RG \& Dunkin AC (1983b) The influence of dietary protein and energy intake on the performance, body composition and energy utilization of pigs growing from 7 to $19 \mathrm{~kg}$. Animal Production 36, 185-192.

Campbell RG \& Taverner MR (1988) Genotype and sex effects on the relationship between energy intake and protein deposition in growing pigs. Journal of Animal Science 66, 676-686.

Campbell RG, Taverner MR \& Curic DM (1984) Effect of feeding level and dietary protein content on the growth, body composition and rate of protein deposition in pigs growing from 45 to $90 \mathrm{~kg}$. Animal Production 38, 233-240.

Campbell RG, Taverner MR \& Curic DM (1985) The influence of feeding level on the protein requirements of pigs between 20 and $45 \mathrm{~kg}$ liveweight. Animal Production 40, 489-496.

Carr JR, Boorman KN \& Cole DJA (1977) Nitrogen retention in the pig. British Journal of Nutrition 37, 143-155.

Close W, Stanier MW \& Sanz Sampelayo MR (1979) The energy requirements for growth in the early-weaned pig. Proceedings of the Nutrition Society 38, 47A.

Close WH, Berschauer F \& Heavens RP (1983) The influence of protein:energy value of the ration and level of feed intake on the energy and nitrogen metabolism of the growing pig. 1. Energy metabolism. British Journal of Nutrition 49, 255-269.

Dunkin AC, Black JL \& James KJ (1986) Nitrogen balance in relation to energy intake in entire male pigs weighing $75 \mathrm{~kg}$. British Journal of Nutrition 55, 201-207.

Fowler VR (1978) Energy requirements of the growing pig. In 
Recent Advances in Animal Nutrition, pp. 73-82 [W Haresign and D Lewis, editors]. London: Butterworths.

Fuller MF, Franklin MF, McWilliam R \& Pennie K (1995) The responses of growing pigs, of different sex and genotype, to dietary energy and protein. Animal Science 60, 291-298.

Kielanowski J (1965) Estimates of the energy cost of protein deposition in growing animals. In Energy Metabolism, European Association of Animal Production Publication no. 11, pp. 13-20 [KL Blaxter, editor]. London: Academic Press.

Kyriazakis I \& Emmans GC (1992) The effects of varying both energy and protein intake on the growth and body composition of pigs. 2. The effects of varying both energy and protein intake. British Journal of Nutrition 68, 615-625.

Kyriazakis I, Dotas D \& Emmans GC (1994) The effect of breed on the relationship between feed composition and the efficiency of protein utilization in pigs. British Journal of Nutrition $\mathbf{7 1}$, 849-859.

Kyriazakis I, Leus K, Emmans GC, Haley CS \& Oldham JD (1993) The effect of breed (Large White $\times$ Landrace $v$. purebred Meishan) on the diets selected by pigs given a choice between two foods that differ in their crude protein contents. Animal Production 56, 121-128.

McCracken KJ, McEvoy J, McAllister A, Lilley J \& Urquhart R (1994) Effects of overfeeding on protein/energy metabolism and body composition of high genetic potential boars. In Energy Metabolism of Farm Animals, European Association of Animal Production Publication no. 76, pp. 217-220 [JF Aguilera, editor]. Madrid: CSIC Publishing Service.

National Research Council (1998) Nutrient Requirement of Swine, 10th revised ed., Washington, DC: National Academy Press.

Nieto R, Lara L, García MA, Gómez F, Zalvide M, Cruz M, Pariente JM, Moreno A \& Aguilera JF (2001a) Evaluación de un sistema integrado de alimentación en el cerdo Ibérico. Análisis del consumo de alimento e índices productivos (Evaluation of an integrated feeding system in the Iberian pig). Sólo Cerdo Ibérico 6, 57-69.
Nieto R, Miranda A, García MA \& Aguilera JF (2001b) Protein and energy interactions in growing Iberian pigs. In Energy Metabolism in Animals, European Association of Animal Production Publication no. 103, pp. 393-396 [A Chwalibog and K Jakobsen, editors]. Wageningen: Wageningen Pers.

Noblet J, Karege C \& Dubois S (1989) Influence of sex and genotype on energy utilization in growing pigs. In Energy Metabolism of Farm Animals, European Association of Animal Production, Publication no. 43, pp. 57-60 [Y van der Honning and WH Close, editors]. Wageningen: Pudoc.

Noblet J, Karege C, Dubois S \& van Milgen J (1999) Metabolic utilization of energy and maintenance requirements in growing pigs: Effects of sex and genotype. Journal of Animal Science 77, 1208-1216.

Rao DS \& McCracken KJ (1991) Effect of energy intake on protein and energy metabolism of boars of high genetic potential for lean growth. Animal Production 52, 499-507.

Rao DS \& McCracken KJ (1992) Energy:protein interactions in growing boars of high genetic potential for lean growth. 2 . Effects on chemical composition of gain and whole-body protein turnover Animal Production 54, 83-93.

Schneider W, Gaus G, Michel A, Susenbeth A \& Menke KH (1982) Effect of level of feeding and body weight on partition of energy in growing pigs. In Energy Metabolism of Farm Animals, European Association of Animal Production, Publication no. 29, pp. 225-228 [A Ekern and F Sundstol, editors]. Norway: Agricultural University of Norway.

Susenbeth A \& Menke KH (1991) The independence of the efficiency of energy utilization for growth $\left(\mathrm{k}_{\mathrm{pf}}\right)$ of the composition of body mass gain in pigs. In Energy Metabolism of Farm Animals, European Association of Animal Production Publication no. 58, pp. 99-102 [C Wenk and M Boessinger, editors]. Zürich: Institut für Nutztierwissenschaften, Gruppen Ernärung, ETH Zentrum.

Whittemore CT \& Fawcett RH (1976) Theoretical aspects of a flexible model to simulate protein and lipid growth in pigs. Animal Production 22, 87-96. 